\title{
Pensamento computacional para crianças pequenas: o que pensam os pais?
}

\section{Larissa Ribeiro da Silva*, Flávia Linhalis Arantes, Fernanda Maria Pereira Freire}

\section{Resumo}

A crescente discussão acerca da utilização de dispositivos móveis por crianças pequenas instiga também o debate sobre ensinar pensamento computacional para crianças. Nesta pesquisa mostramos a opinião dos principais responsáveis por crianças de 2 a 6 anos a respeito do tema.

\section{Palavras-chave:}

Pensamento computacional, tecnologias móveis, crianças.

\section{Introdução}

Não se pode negar que as novas tecnologias se incorporam ao cotidiano das pessoas cada vez mais cedo. Informações divulgadas pelo Kids Online ${ }^{1}$ mostram que $11 \%$ das crianças e adolescentes realizam 0 primeiro acesso à internet com idade inferior a 6 anos. Esse acesso, cada vez mais precoce, gera um debate sobre os malefícios e benefícios que 0 uso de dispositivos móveis pode causar ${ }^{2,3}$.

À vista da crescente discussão acerca do tema, realizamos um estudo com o objetivo de conhecer a opinião dos pais (ou principais responsáveis) das crianças sobre o uso de tecnologias móveis. Para tanto, elaboramos um questionário para capturar informações sobre os hábitos das crianças pequenas (de 2 a 6 anos) com relação ao uso desse tipo de tecnologia 4 .

Neste resumo apresentamos especificamente a opinião dos responsáveis pelas crianças acerca de um tema que tem ganhado atenção nos últimos anos - o pensamento computacional, isto é, a capacidade de resolver problemas e conceber sistemas com base em conceitos fundamentais da ciência da computação ${ }^{5}$, o que envolve conhecer programação de computadores, entre outros conceitos.

\section{Resultados e Discussão}

No questionário fizemos a seguinte pergunta: "você acha importante que as crianças de hoje em dia aprendam a programar computadores, isto é, aprendam lógica de programação?"

A pergunta em questão tem 161 respostas de um total de 163 respondentes que deixaram suas opiniões*.

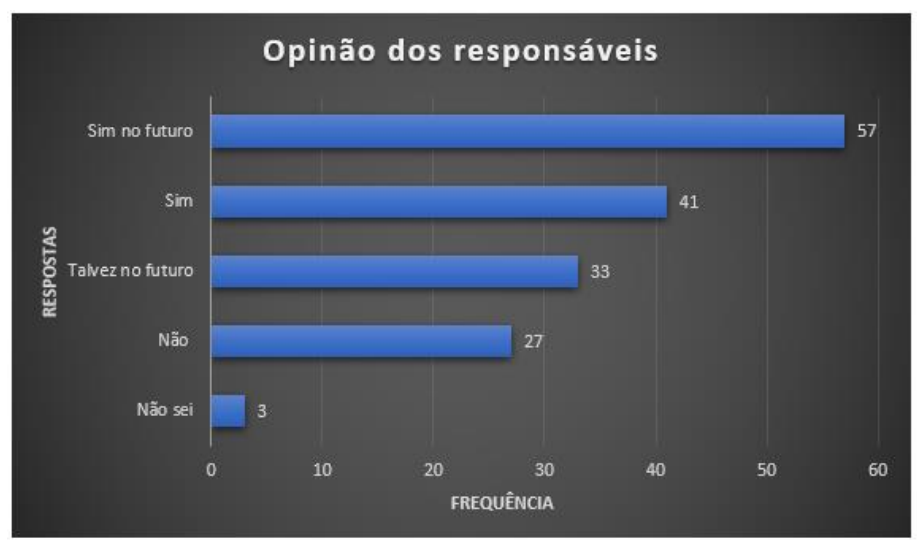

Figura 1 - Gráfico com opinião dos pais sobre o desenvolvimento do pensamento computacional em crianças pequenas.
Como podemos observar no gráfico da Figura 1: $24,5 \%$ concordam com a importância dessa aprendizagem, como o respondente que comentou "Sou da área de computação $e$ entendo os benefícios que isso pode proporcionar. Desde que seja algo voltado a idade dele (que ainda é novo, mas acredito que aos 6 anos poderia começar). Baseado em alguma estratégia lúdica"; $35,4 \%$ dos responsáveis confirmaram é importante que uma criança aprenda lógica de programação, o que é um percentual relevante, entretanto eles acreditam que esse ensino deveria ser realizado no futuro; $20,5 \%$ não tem certeza sobre a importância desse conteúdo para a criança e caso essa aprendizagem ocorra, seria mais adequada futuramente, como pode ser verificado pela resposta "Hoje acredito que isso seja uma escolha da criança e eu, particularmente, não incentivaria, pelo menos enquanto ela for mais nova, pois não gosto que fique muito tempo em frente ao computador ou afins"; $16,8 \%$ não concorda com a aprendizagem deste conteúdo na fase infantil, como quem comentou "As crianças não devem ter amplo acesso a aparelhos pois entendemos que prejudica 0 desenvolvimento" e 1,8\% não soube responder.

\section{Conclusões}

Entendemos que a apropriação do pensamento computacional por parte de crianças pequenas é ainda um campo em construção, avaliado de maneira pouco crítica. Nosso objetivo é contribuir para uma análise mais fundamentada, que tem como uma das bases inicial a opinião daqueles que mais se se mostram zelosos com o futuro das crianças - seus cuidadores/responsáveis principais.

${ }^{1}$ CGI.br Comitê Gestor de Internet no Brasil (2018) "TIC Kids Online Brasil Pesquisa sobre o uso da Internet por Crianças e Adolescentes no Brasil". Disponível<https://cetic.br/media/docs/publicacoes/2/tic_kids_online_2017_li vro_eletronico.pdf $>$. Acesso em: 19 fev. 2019

2 Silva, T. O.; Silva, L. T. G. (2017) "Os impactos sociais, cognitivos e afetivos sobre a geração de adolescentes conectados às tecnologias digitais". Revista Psicopedagogia, São Paulo, v. 34, n. 103, p. 87-97, 2017.

3 UNESCO (2013) "Diretrizes de políticas da UNESCO para a aprendizagem móvel". Disponível: <https://unesdoc.unesco.org/ark:/48223/pf0000227770>. Acesso em 20 fev. 2019

${ }^{4}$ Silva, L. R; Arantes, F. L.; Freire, F. M. P. (2019) "Tecnologias móveis e crianças pequenas - questões iniciais". Relatório Técnico do NIED, n. 1, 2019. Campinas, Brasil. No prelo. Estará disponível em: https://www.nied.unicamp.br/biblioteca/relatorios-tecnicos/

5 Wing, J. M. Computational thinking. Communications of the ACM, v. 49, n. 3, p. 33-35, 2006

* Esta pesquisa foi aprovada pelo Comitê de Ética, número do CAAE: 89010318.0.0000.8142. 